\author{
G. Ryzhakova \\ Doctor of Economics, Professor, Head of the Department of \\ Management in Construction \\ galinar2011@gmail.com,orcid.org/0000-0002-7875-9768 \\ Kyiv National University of Construction and Architecture, Ukraine
}

\section{K. Chupryna}

Candidate of Technical Sciences, Associate Professor of Management in Construction

immens@ukr.net, orcid.org/0000-0001-5518-3607

Kyiv National University of Construction and Architecture, Ukraine

\section{Ivakhnenko}

Doctor of Economics, Associate Professor, Professor of the Department of Management in Construction ivakhnenkoirina@ukr.net,orcid.org/0000-0001-8561-9109

Kyiv National University of Construction and Architecture, Ukraine

\section{A. Derkach}

Graduate student of the Department of Management in Construction andriiderkach01@gmail.com, orcid.org/0000-0001-5225-0018 Kyiv National University of Construction and Architecture, Ukraine

\section{Huliaiev}

Graduate student of the Department of Construction Management ca3515ce@gmail.com,orcid.org/0000-0002-0223-2142

Kyiv National University of Construction and Architecture, Ukraine

\title{
EXPERT-ANALYTICAL MODEL OF MANAGEMENT QUALITY ASSESSMENT AT A CONSTRUCTION ENTERPRISE
}

\begin{abstract}
This article develops an expert-analytical model for assessing the quality of process-oriented management of construction companies. The model differs in a two-tier approach to object evaluation by pre-evaluating the characteristics of objects and their parameters. Assessments were made in connection with the time and financial costs of resources that allow to forming an expert group, conduct a survey and analyzing its results. These results were conducted by the method of written questionnaires, which are divided into three groups: general information about the expert (age, experience, specialty, etc.), the main questions related to the problems being analyzed or evaluated, additional questions to determine the rationale for answers, competence of experts, etc. The list of possible linguistic estimations of characteristics and parameters and their numerical equivalents is formed that will give the chance to provide quality of process-oriented management on the basis of the analyzed integrated indicators of quality of management of the building enterprise. A generalized assessment of the characteristics of each of the experts of the formed group in the expert-analytical model is also formed. The list of objects, parameters and their components which are intended for an estimation of quality of management at the building enterprise is generalized. The dynamic analysis of the integrated indicator of management quality allows the institutional level of contractors to rationally plan the activities of the construction
\end{abstract}


company and adjust the work in sectors (financial, production, resource, etc.) for which negative evaluations were obtained.

Key words: construction contractors, quality management system, process-oriented management, expert-analytical models.

\section{Introduction}

To assess the quality of process-oriented management in a construction company, it is necessary to perform a number of stages (from the formation of an expert group to the analysis of the assessed objects and the calculation of an integrated indicator of management quality). These stages are closely related.

\section{Literature Review}

Studies of theoretical and practical issues of assessing the quality of management are reflected in the works of world historical thinkers (Aristotle, E. Kant, G. Hegel) and modern scientists - economists Aristov O.V., Basovsky L.E., Chupryna Y.A. [3-4], Bozhenko L.I., Pys'mennyy O.M. [12], Gerusa O.V, Ryzhakova G.M [1], Gludkina OP, Pokolenko V.O[7], Dubovogo, PI, Kulikova P.M. [2], Belenkova O.Y. [11], Goiko A.F. [10], Stetsenko S.P. [9], Lycha V.M. [8], Fedorenko V.G. [6] and others.

In classical systems, depending on the amount of data used in the expert survey, the formation of objects and characteristics, either the management team or the decision-maker performs the selection of experts and evaluation. In the expert-analytical model for assessing the quality of management can be limited to the decision maker. However, if there are opportunities at the enterprise, it is necessary to form a group of managers, experts and heads of departments, who after the evaluation will be able to analyze the results and immediately take the necessary measures to improve the efficiency of current projects, reduce costs and increase financial results and more. The management team should involve the widest possible range of specialists whose competence is related to the objects of evaluation. According to the objects and characteristics, the group of managers of the expert-analytical model should include financial analysts and financiers, managers (HR-managers, time managers, etc.), marketers, specialists in the organization of construction, etc. [1]

Expert evaluation is associated with the cost of resources, primarily time and financial, which allow forming an expert group, conducting a survey and analyzing its results. It is possible to form a pattern that applies to all expert models: the larger the number of members of the expert group, the more reliable the results of the examination. However, attracting more experts involves higher financial costs. That is, the funds allocated by the construction company to assess the quality of management limit the number of experts. It is important in this case to select a group in such a way as to invest in the allocated funds and at the same time ensure the representation of experts with all the necessary competencies. In general, in addition to competence, there are the following characteristics of experts that ensure the reliability of the results: creativity, the required level of conformism, collectivism and selfcriticism, constructive thinking. These characteristics, in addition to competence, are usually determined qualitatively. To obtain a quantitative assessment of competence at the stage of formation of the expert group, it is necessary to conduct a survey of group members on the possibility of the presence of other members. According to the results of the survey, a survey matrix is formed $\left\{a_{i j}\right\}_{i, j=1}^{k}$, where $k$ - the number of experts proposed for inclusion in the group. Matrix elements $a_{i j}=1$, if $j$-th expert called $i$-th. If $j$-th the expert does not call $i$-th, then $a_{i j}=0$. The coefficient of competence of each expert is determined by the formula: 


$$
w_{i}=\frac{1}{\sum_{i=1}^{k} \sum_{j=1}^{k} a_{i j}} \cdot \sum_{j=1}^{k} a_{i j}, i=\overline{1, k}
$$

where $w_{i}$-coefficient of competence $i$-th expert. Moreover, these coefficients are normalized, i.e. their sum is equal to one:

$$
\sum_{i=1}^{k} w_{i}=1
$$

In addition to competence, it is important to calculate the level of reliability of expert assessments. To calculate this characteristic, it is necessary to have a sufficient amount of preliminary assessments of each of the experts, as well as to assess the significance of assessments to solve the problems that were assessed in practice. It should be noted that often such information may be missing. [3-4]

The level of reliability of expert estimates $d_{i}$ is estimated by the formula:

$$
d_{i}=\frac{u_{i}}{u}, i=\overline{1, k}
$$

where $u_{i}$ - number of cases, when $i$ - th the expert provided decisions that were confirmed in practice, $u$ - the total number of cases in which the expert participated in the evaluation.

Then the level of reliability of each expert in the group being formed, $\bar{d}_{i}$ determined by the formula:

$$
\bar{d}_{i}=\frac{d_{i}}{\sum_{i=1}^{k} d_{i}}, i=\overline{1, k}
$$

where $k$ - number of experts in the group.

Based on the calculated characteristics it is possible to form the generalized estimation of characteristics of each of experts of the formed group in expert-analytical model:

$$
r_{i}=\beta \cdot w_{i}+(1-\beta) \cdot \bar{d}_{i}, i=\overline{1, k}
$$

where $r_{i}$ - generalized assessment of the characteristics of experts, $\bar{d}_{i}$ - the level of reliability of expert assessments, $w_{i}$ - coefficient of competence of experts, $k$ - number of experts in the group, $\beta \in[0,1]$ - a parameter that determines the weight of the characteristics in the generalized estimate. If there is no information on the level of reliability of expert assessments, it is accepted $\beta=1$. In other cases, you can take $\beta=0.5$.

To use estimates $r_{i}$ in the constructed expert-analytical model, in case the condition of equality of the sum of estimations of unit is not fulfilled, that is

$$
\sum_{i=1}^{k} r_{i}=1
$$

they must be normalized by the formula: 


$$
r_{i}^{H}=\frac{r_{i}}{\sum_{i=1}^{k} r_{i}}, i=\overline{1, k}
$$

where $r_{i}^{H}$ - normalized generalized assessment of the characteristics of experts,

$$
\sum_{i=1}^{k} r_{i}^{H}=1
$$

At the next stage it is necessary to form a list of possible linguistic estimates of characteristics and parameters and their numerical equivalents. In the constructed expert-analytical model the ten-point scale in which each member of expert group puts

the linguistic estimation to each parameter or characteristic of estimation is considered. The list of linguistic estimates and numerical equivalents in the constructed model is given in the Table 1.

\begin{tabular}{|c|c|c|}
\hline № & $\begin{array}{l}\text { Linguistic derivation of the state of quality assurance of process-oriented } \\
\text { management on the basis of the analyzed integrated indicators of quality of } \\
\text { management of the construction enterprise }\end{array}$ & $\begin{array}{l}\text { The range of values of } \\
\text { the integrated indicator } \\
\text { of management quality }\end{array}$ \\
\hline 1 & $\begin{array}{l}\text { "State of excellent efficiency and stability." The construction company } \\
\text { effectively uses and redistributes labor, material and technical resources. } \\
\text { The company provides high adaptive capacity due to a significant level of } \\
\text { employee motivation, financial stability, efficiency of time management, } \\
\text { information. The resilience of the company to crisis conditions is associated } \\
\text { with a sufficient level of profit growth and gaining competitive advantage. }\end{array}$ & From 0.73 to 1 inclusive \\
\hline 2 & $\begin{array}{l}\text { "State of good efficiency and sustainability." The construction company } \\
\text { has a fairly high rate of financial stability, it effectively uses resources and } \\
\text { implements management functions. The company fulfills all obligations to } \\
\text { partners properly. In general, this company can be included in regional and } \\
\text { international projects and relevant tenders. }\end{array}$ & $\begin{array}{l}\text { From } 0.51 \text { to } 0.73 \\
\text { inclusive }\end{array}$ \\
\hline 3 & $\begin{array}{l}\text { "State of sufficient efficiency and sustainability." The construction company } \\
\text { provides the necessary industry standards for resource provision, has a } \\
\text { sufficient level of efficiency in the management of financial, labor and } \\
\text { logistical resources. In general, the assessment shows that the company } \\
\text { fulfills its obligations to customers and can be included in projects and } \\
\text { tenders on a regional scale. }\end{array}$ & $\begin{array}{l}\text { From } 0.34 \text { to } 0.51 \\
\text { inclusive }\end{array}$ \\
\hline 4 & $\begin{array}{l}\text { "State of satisfactory efficiency and sustainability." The construction company } \\
\text { has sufficient reserves to meet its obligations to partners and customers, } \\
\text { is able to implement projects to avoid the impact of crisis phenomena, } \\
\text { at a satisfactory level ensures the quality of management and resource } \\
\text { management. In general, the obtained assessment of the integrated indicator } \\
\text { of management quality indicates that the company can be included in projects } \\
\text { and tenders at the local level, but can also be included in projects at the } \\
\text { regional level, provided sufficient provision of some basic characteristics } \\
\text { (financial security, logistics). control, etc.) }\end{array}$ & $\begin{array}{l}\text { From } 0.22 \text { to } 0.34 \\
\text { inclusive }\end{array}$ \\
\hline
\end{tabular}

Table 1. Linguistic-numerical scale for assessing quality assurance [12] 


\begin{tabular}{|c|l|l|}
\hline 5 & $\begin{array}{l}\text { "Low state of quality management." The construction company still has } \\
\text { sufficient or significant resources to provide anti-crisis measures, but ensuring } \\
\text { financial stability for the effectiveness of resource management is low. }\end{array}$ & $\begin{array}{l}\text { From } 0.13 \text { to } 0.22 \\
\text { inclusive }\end{array}$ \\
\hline 6 & $\begin{array}{l}\text { "Critical state of management quality assurance." The construction company is } \\
\text { in conditions of inefficient management of resources, time and information. } \\
\text { The company has low employee motivation, insufficient control and } \\
\text { coordination. Achieving the goal at the enterprise in terms of ensuring the } \\
\text { planned increase in profits and the development of new markets in general is } \\
\text { unstable (successful measures alternate with failures). The company needs an } \\
\text { urgent investment, modernization of the management system and adjustment } \\
\text { of the organizational structure of the enterprise. }\end{array}$ & $\begin{array}{l}\text { inclusive } \\
7\end{array}$ \\
\hline $\begin{array}{l}\text { "Crisis situation". The construction company is in crisis. All the characteristics } \\
\text { that determine the integrated indicator of management quality are at a low } \\
\text { level, which indicates the lack of opportunities for the company to get out of } \\
\text { this state without infusion of investment, which in general may exceed the } \\
\text { total assets of the enterprise. }\end{array}$ & Less than 0.06 \\
\hline
\end{tabular}

The objects in the expert-analytical model of quality management assessment will be: the quality of resource provision (we will denote this object by $O_{1}$ ), quality of implementation of management functions (this object is denoted by $\mathrm{O}_{2}$ ), the quality of achieving the goal of the construction company (denote this object by $O_{3}$ ). Evaluation for objects $O_{1}$ and $O_{2}$ will be conducted at two levels: at the level of parameters and characteristics of objects. For the object $\mathrm{O}_{3}$ evaluation will be carried out only at the level of characteristics.

Features $i$-ih objects will be denoted by $p_{j}^{i}$, where $j=\overline{1, n_{i}}, n_{i}$ - the number of characteristics of the object $O_{i}$. In the general case, additional objects for evaluation can be added to the expert-analytical model, so through $l$ we will indicate the number of objects (in our case $l=3$ ).

The parameters of the characteristics will be denoted by $q_{h}\left(p_{j}^{i}\right)$, where $h=\overline{1, m_{j}^{i}}, m_{j}^{i}-$ number of parameters $j$-i characteristics $i$-th object. Table 2 summarizes the list of objects, parameters and their components that are designed to assess the quality of management in the construction company. 
Table 2. The content of parameters and characteristics of integrated components in assessing the quality of management in a construction company [7-9]

\begin{tabular}{|c|c|c|c|}
\hline \multirow{2}{*}{$\begin{array}{l}\text { The name } \\
\text { (object) } \\
\text { of the } \\
\text { integrated } \\
\text { component }\end{array}$} & \multicolumn{2}{|r|}{ Components (object) of the integrated component } & \multirow{2}{*}{$\begin{array}{l}\text { Units of } \\
\text { measurement } \\
\text { of parameters }\end{array}$} \\
\hline & Features & Parameters & \\
\hline \multirow{10}{*}{ 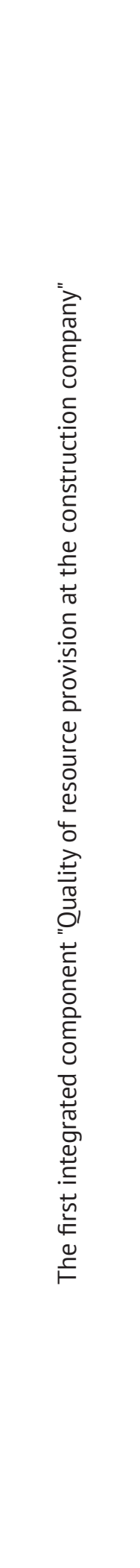 } & \multirow{4}{*}{$\begin{array}{l}p_{1}^{1}- \\
\text { Provision } \\
\text { of labor } \\
\text { resources }\end{array}$} & $\begin{array}{l}q_{1}\left(p_{1}^{1}\right) \text { - Labor productivity is generally defined as the ratio } \\
\text { of value to available resources or the number of manufactured } \\
\text { products per unit of labor per year. Also, this indicator can be } \\
\text { determined in relative units by expert evaluation. }\end{array}$ & $\begin{array}{l}\text { Units of } \\
\text { output. / pers. } \\
\text { * year and } \\
\text { relative units }\end{array}$ \\
\hline & & $\begin{array}{l}q_{2}\left(p_{1}^{1}\right) \text { - Motivation. It is determined on the basis of expert } \\
\text { evaluation and reflects the desire of employees to obtain } \\
\text { certain benefits, including financial, through employment in } \\
\text { the enterprise. }\end{array}$ & Relative units \\
\hline & & $\begin{array}{l}q_{3}\left(p_{1}^{1}\right) \text { - Provision of all types of work by employees of the } \\
\text { required qualification. Defined as a percentage of the total } \\
\text { number of employees who perform work according to the } \\
\text { level of qualification and education. Also, this parameter can } \\
\text { be estimated by experts according to the above scale. }\end{array}$ & $\begin{array}{l}\% \text { and } \\
\text { relative units }\end{array}$ \\
\hline & & $\begin{array}{l}q_{4}\left(p_{1}^{1}\right)-\text { General level of training and qualification of } \\
\text { employees. This parameter is defined as the amount of money } \\
\text { received as a result of work per unit of labor during the year. }\end{array}$ & $\begin{array}{l}\text { Thousands } \\
\text { UAH / person } \\
{ }^{*} \text { year and } \\
\text { relative units }\end{array}$ \\
\hline & \multirow{3}{*}{$\begin{array}{l}p_{2}^{1}- \\
\text { Financial } \\
\text { security }\end{array}$} & $\begin{array}{l}q_{1}\left(p_{2}^{1}\right) \text { - The overall efficiency of financial resources } \\
\text { management is assessed by financiers in relative units. }\end{array}$ & Relative units \\
\hline & & $\begin{array}{l}q_{2}\left(p_{2}^{1}\right) \text { - The level of wages of employees (taking into } \\
\text { account the average. By state). The parameter is estimated in } \\
\text { monetary units, reflecting the average salary at the enterprise } \\
\text { in thousands of UAH, as well as in relative units, and the value } \\
\text { of } 10 \text { on the scale will correspond to the maximum level of } \\
\text { wage compliance with the work required, the value of } 1 \text { - the } \\
\text { minimum level. }\end{array}$ & $\begin{array}{l}\text { Thousands } \\
\text { UAH and } \\
\text { relative units }\end{array}$ \\
\hline & & $\begin{array}{l}q_{3}\left(p_{2}^{1}\right) \text { - Availability of an investment fund and } \\
\text { opportunities for additional financial infusions. A parameter } \\
\text { that determines the financial stability and ability to } \\
\text { participate in joint projects of a construction company. }\end{array}$ & Relative units \\
\hline & \multirow{3}{*}{$\begin{array}{l}p_{3}^{1}- \\
\text { Material and } \\
\text { technical } \\
\text { support }\end{array}$} & $\begin{array}{l}q_{1}\left(p_{3}^{1}\right) \text { - Provision and efficiency of management of material } \\
\text { production resources. The parameter can be estimated as the } \\
\text { percentage of material production resources available to the } \\
\text { enterprise in relation to the total amount of all necessary } \\
\text { resources of the enterprise. The parameter is also evaluated in } \\
\text { relative units by experts. }\end{array}$ & $\begin{array}{l}\% \text {, relative } \\
\text { units }\end{array}$ \\
\hline & & $\begin{array}{l}q_{2}\left(p_{3}^{1}\right) \text { - Provision and efficiency of management of } \\
\text { technical production resources. The parameter can be } \\
\text { estimated as the percentage of material production resources } \\
\text { available to the enterprise in relation to the total amount of } \\
\text { all necessary resources of the enterprise. The parameter is } \\
\text { also evaluated in relative units by experts. }\end{array}$ & $\begin{array}{l}\% \text {, relative } \\
\text { units }\end{array}$ \\
\hline & & $\begin{array}{l}q_{3}\left(p_{3}^{1}\right) \text { - Equipping with computers and means of } \\
\text { communication as a percentage of the total number of needs. }\end{array}$ & $\begin{array}{l}\% \text {, relative } \\
\text { units }\end{array}$ \\
\hline
\end{tabular}




\begin{tabular}{|c|c|c|c|}
\hline & \multirow{6}{*}{$\begin{array}{l}p_{4}^{1}-\text { Time } \\
\text { management } \\
\text { efficiency }\end{array}$} & $\begin{array}{l}q_{1}\left(p_{4}^{1}\right) \text { - The structure of working time is estimated in } \\
\text { relative units. A value of } 10 \text { means the maximum efficiency of } \\
\text { work for a given structure of working time, } 1 \text { - the minimum. }\end{array}$ & Relative units \\
\hline & & $\begin{array}{l}q_{2}\left(p_{4}^{1}\right) \text { - The efficiency of the distribution and use of } \\
\text { working time is assessed in relative terms by experts. }\end{array}$ & Relative units \\
\hline & & $\begin{array}{l}q_{3}\left(p_{4}^{1}\right) \text { - Time reserves are determined in working hours } \\
\text { and in relative units according to the given scale. }\end{array}$ & $\begin{array}{l}\text { Year. slave. } \\
\text { time and } \\
\text { relative units }\end{array}$ \\
\hline & & $\begin{array}{l}q_{4}\left(p_{4}^{1}\right) \text { - Taking into account the seasonality of the } \\
\text { construction process. A value of } 10 \text { means that the seasonality } \\
\text { of the construction process is fully taken into account at all } \\
\text { stages of construction. A value of } 1 \text { means that seasonality is } \\
\text { not taken into account at all. }\end{array}$ & Relative units \\
\hline & & $\begin{array}{l}q_{5}\left(p_{4}^{1}\right) \text { - Taking into account the duration of the production } \\
\text { cycle is estimated in relative units by experts. }\end{array}$ & Relative units \\
\hline & & $\begin{array}{l}q_{6}\left(p_{4}^{1}\right) \text { - Consideration of process mismatch construction } \\
\text { with the reporting period is estimated in relative units. }\end{array}$ & Relative units \\
\hline & \multirow{4}{*}{$\begin{array}{l}p_{5}^{1}- \\
\text { Efficiency of } \\
\text { information } \\
\text { transmission } \\
\text { and } \\
\text { exchange }\end{array}$} & $\begin{array}{l}q_{1}\left(p_{5}^{1}\right)-\text { The completeness, reliability and quality of } \\
\text { information is assessed by experts on the basis of the above } \\
\text { scale. }\end{array}$ & Relative units \\
\hline & & $\begin{array}{l}q_{2}\left(p_{5}^{2}\right) \text { - The process of exchanging information at a } \\
\text { construction company. The effectiveness of the information } \\
\text { exchange process is indicated by the assessments of experts } \\
\text { from the interval }[1,10] \text {. }\end{array}$ & Relative units \\
\hline & & $\begin{array}{l}q_{3}\left(p_{5}^{1}\right) \text { - The existence of limits of competence and } \\
\text { responsibility for the collection and exchange of information } \\
\text { is assessed by experts on the basis of relative indicators. }\end{array}$ & Relative units \\
\hline & & $\begin{array}{l}q_{4}\left(p_{5}^{1}\right) \text { - Availability of information base at the construction } \\
\text { company. Value } 10 \text { - the company has a base, } 1 \text { - no base. }\end{array}$ & Relative units \\
\hline \multirow{5}{*}{ 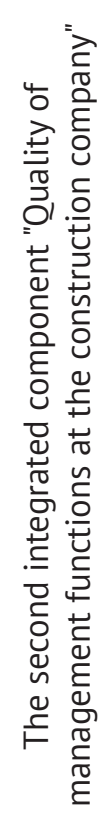 } & \multirow{5}{*}{$\begin{array}{l}p_{1}^{2}- \\
\text { Planning }\end{array}$} & $\begin{array}{l}q_{1}\left(p_{1}^{2}\right) \text { - The formation of the strategic goal of the } \\
\text { construction company is assessed by analogy with other } \\
\text { parameters by experts on the basis of the given ten-point } \\
\text { rating scale. }\end{array}$ & Relative units \\
\hline & & $\begin{array}{l}q_{2}\left(p_{1}^{2}\right) \text { - Obtaining and analyzing information about key } \\
\text { customers and partners. If such an analysis takes place, the } \\
\text { expert gives } 10 \text { points, if not, then } 1 .\end{array}$ & Relative units \\
\hline & & $\begin{array}{l}q_{3}\left(p_{1}^{2}\right) \text { - Obtaining and analyzing information about } \\
\text { competitors of the enterprise. If such an analysis takes place, } \\
\text { the expert gives } 10 \text { points, if not, then } 1 .\end{array}$ & Relative units \\
\hline & & $\begin{array}{l}q_{4}\left(p_{1}^{2}\right) \text { - Modification of business processes. Modifiability of } \\
\text { business processes is determined by experts. }\end{array}$ & Relative units \\
\hline & & $\begin{array}{l}q_{5}\left(p_{1}^{2}\right) \text { - Resource planning. The quality of resource } \\
\text { planning is determined in relative units on the basis of an } \\
\text { expert survey. If the quality is high, the experts evaluate this } \\
\text { parameter at level } 10 \text {, otherwise if the quality is very low - at } \\
\text { level } 1 .\end{array}$ & Relative units \\
\hline
\end{tabular}




\begin{tabular}{|c|c|c|}
\hline \multirow{4}{*}{$\begin{array}{l}p_{2-}^{2} \\
\text { Organization }\end{array}$} & $\begin{array}{l}q_{1}\left(p_{2}^{2}\right) \text { - The construction of the organizational structure } \\
\text { of the enterprise is assessed by experts. If the quality of the } \\
\text { organizational structure, according to the expert, is high, then } \\
\text { he sets } 10 \text { points, otherwise - lower values. }\end{array}$ & Relative units \\
\hline & $\begin{array}{l}q_{2}\left(p_{2}^{2}\right) \text { - The organization of the production process is } \\
\text { evaluated by analogy with other parameters by experts on the } \\
\text { basis of the given ten-point evaluation scale. }\end{array}$ & Relative units \\
\hline & $\begin{array}{l}q_{3}\left(p_{2}^{2}\right) \text { - Distribution of powers and responsibilities of } \\
\text { employees. Expert assessments determine how effectively } \\
\text { the distribution of powers among employees is carried out. } \\
\text { Efficiency is determined by the subjective opinion of experts } \\
\text { on a scale from } 1 \text { to } 10, \text { where } 1 \text { point equals low efficiency, } \\
10 \text { - very high efficiency. }\end{array}$ & Relative units \\
\hline & $\begin{array}{l}q_{4}\left(p_{2}^{2}\right)-\text { Ensuring the process of creating new values for } \\
\text { customers and the efficiency of their production is determined } \\
\text { on the basis of an expert survey on the above scale. }\end{array}$ & Relative units \\
\hline \multirow{5}{*}{$p_{3}^{2}-$ Control } & $\begin{array}{l}q_{1}\left(p_{3}^{2}\right)-\text { Calculation and analysis of customer satisfaction. A } \\
\text { value of } 10 \text { indicates that customers are completely satisfied } \\
\text { with the quality of products, } 1 \text { - completely dissatisfied. The } \\
\text { overall result is determined by experts on the basis of these } \\
\text { estimates. }\end{array}$ & Relative units \\
\hline & $\begin{array}{l}q_{2}\left(p_{3}^{2}\right)-\text { Calculation and analysis of the results obtained } \\
\text { in the production process. If the results obtained in the } \\
\text { production process are significant, the expert evaluates this } \\
\text { parameter at } 10 \text { points, otherwise - } 1 \text { point. }\end{array}$ & Relative units \\
\hline & $\begin{array}{l}q_{3}\left(p_{3}^{2}\right)-\text { Control over the rational use of resources. The } \\
\text { parameter determines how the construction company provides } \\
\text { control over the rational use of resources. If the control } \\
\text { is provided at a high level, the expert gives a score of } 10 \text {, } \\
\text { otherwise }-1 \text {. }\end{array}$ & Relative units \\
\hline & $\begin{array}{l}q_{4}\left(p_{3}^{2}\right) \text { - Correspondence of results of activity to the } \\
\text { strategic purpose of the enterprise is estimated by analogy } \\
\text { with other parameters by an expert way on the basis of the } \\
\text { resulted ten-point scale of estimation. }\end{array}$ & Relative units \\
\hline & $\begin{array}{l}q_{5}\left(p_{3}^{2}\right) \text { - Control over the quality of implementation of } \\
\text { business plans of the construction company is assessed by } \\
\text { analogy with other parameters by experts on the basis of the } \\
\text { given ten-point rating scale. }\end{array}$ & Relative units \\
\hline \multirow[b]{2}{*}{$\begin{array}{l}p_{4-}^{2} \\
\text { Motivation }\end{array}$} & $\begin{array}{l}q_{1}\left(p_{4}^{2}\right) \text { - Presence at the enterprise of corporate structure. } \\
\text { A value of } 1 \text { means its absence, } 10 \text { - the presence and } \\
\text { effectiveness, intermediate values between } 1 \text { and } 10 \\
\text { determine how effective the corporate structure } \\
\text { (more value - more effective, less value - less effective). }\end{array}$ & Relative units \\
\hline & $\begin{array}{l}q_{2}\left(p_{4}^{2}\right) \text { - Availability of opportunities for professional } \\
\text { growth, training and self-realization of employees. Experts } \\
\text { evaluate this characteristic on the scale of conformity of } \\
\text { linguistic estimates of numerical (score) values. If experts } \\
\text { evaluate the characteristic at the level of } 10 \text {, then the } \\
\text { company has all the opportunities for professional growth, } 1 \text { - } \\
\text { no opportunities for growth, learning and self-realization. }\end{array}$ & Relative units \\
\hline
\end{tabular}




\begin{tabular}{|c|c|c|c|}
\hline & & $\begin{array}{l}q_{3}\left(p_{4}^{2}\right) \text { - Overall employee satisfaction with the results of } \\
\text { their work is measured in relative units. A value of } 10 \text { means } \\
\text { that employees are completely satisfied with the results of } \\
\text { their work, } 1 \text { - complete dissatisfaction. }\end{array}$ & Relative units \\
\hline & \multirow{3}{*}{$\begin{array}{l}p_{5}^{2}- \\
\text { Координація }\end{array}$} & $\begin{array}{l}q_{1}\left(p_{5}^{2}\right) \text { - The presence of a conflict resolution system at } \\
\text { the enterprise is assessed on a scale: } 1 \text { - the company does } \\
\text { not have a conflict resolution system, } 10 \text { - there is a conflict } \\
\text { resolution system. }\end{array}$ & Relative units \\
\hline & & $\begin{array}{l}q_{2}\left(p_{5}^{2}\right) \text { - The analysis of deviations from realization of } \\
\text { the set purpose is estimated by an expert way. A value of } 10 \\
\text { means that the deviations are minimal, } 1 \text { - the deviations are } \\
\text { maximum. }\end{array}$ & Relative units \\
\hline & & $\begin{array}{l}q_{3}\left(p_{5}^{2}\right) \text { - Coordination of other management functions. } \\
\text { This parameter determines the extent to which all of the } \\
\text { above management functions are coordinated to achieve the } \\
\text { strategic goal of the enterprise. }\end{array}$ & Relative units \\
\hline \multirow{2}{*}{ 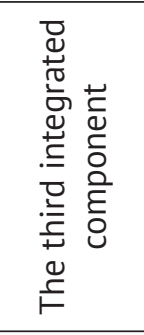 } & \multicolumn{2}{|c|}{$\begin{array}{l}p_{1}^{2} \text { - Planning. This characteristic is evaluated in relative units and } \\
\text { determines how much planning of the enterprise allows to ensure the } \\
\text { implementation of the strategic goal. }\end{array}$} & Relative units \\
\hline & \multicolumn{2}{|c|}{$\begin{array}{l}p_{2}^{3}-\text { Gaining competitive advantage. Involves the study of the competitive } \\
\text { environment in order to modify the production process so as to obtain } \\
\text { qualities that prevail over competitors. Evaluation is carried out by experts } \\
\text { according to the given scale. }\end{array}$} & Relative units \\
\hline \multirow{3}{*}{ 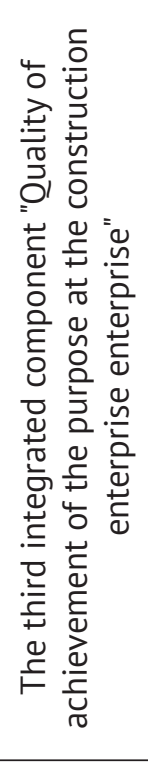 } & \multicolumn{2}{|c|}{$\begin{array}{l}p_{3}^{3} \text { - Implementation of stages in the company's exit from the crisis. If } \\
\text { preliminary assessments of the integrated quality indicator indicate the } \\
\text { presence of crisis phenomena, the implementation of measures to overcome } \\
\text { these phenomena is assessed on this indicator according to the scale: a } \\
\text { value of } 10 \text { means maximum efficiency in implementing the exit plan, } 1 \text { - the } \\
\text { absence of any positive dynamics in the context of overcoming the crisis at } \\
\text { the enterprise. }\end{array}$} & Relative units \\
\hline & \multicolumn{2}{|c|}{$\begin{array}{l}p_{4}^{3} \text { - Development of new markets. This characteristic is evaluated expertly } \\
\text { on the basis of a ten-point scale, in which the value of } 10 \text { determines that the } \\
\text { company is intensively developing new markets, } 1 \text { - the lack of dynamics in } \\
\text { relation to this characteristic. }\end{array}$} & Relative units \\
\hline & \multicolumn{2}{|c|}{$\begin{array}{l}p_{5}^{3} \text { - Use of environmentally friendly materials and preservation of the } \\
\text { environment. One of the characteristics that can be part of the company's } \\
\text { goal is to preserve the environment and the use of environmentally friendly } \\
\text { building materials. Estimation of this characteristic is realized by an expert } \\
\text { way on the basis of relative indicators which are set in a scale of conformity of } \\
\text { linguistic estimations to numerical. }\end{array}$} & Relative units \\
\hline
\end{tabular}

The survey of experts can be conducted by the method of questionnaires in writing. The content of the question can be divided into three groups: general information about the expert (age, experience, specialty, etc.), the main questions related to the problems being analyzed or evaluated, additional questions to determine the rationale for answers, competence of experts, etc. . In the expert-analytical model, all questions will be related to the quality of providing parameters and characteristics of each of the objects.

After conducting a survey of the expert group, the results are processed. The input for it is numerical data that expresses the preferences and assessments of experts. The purpose of processing is to obtain hidden data contained in the benefits and the calculation of generalized estimates. Based on the results of processing, a solution to the problem is formed. [6-9] 
To assess the performance of each of the characteristics of the objects, it is necessary to precalculate the coefficient of competence of experts $r_{c}, c=\overline{1, k}$. Also, the weights of indicators are determined in advance, which reflect the weight of the estimates of each indicator in the evaluation of the characteristic. Let us denote the weights by $\omega_{h}, h=\overline{1, m_{j}^{i}}$, moreover

$$
\sum_{h=1}^{m_{j}^{i}} \omega_{h}=1,
$$

that is, the weights are normalized.

Coefficients of competence of experts are also standardized:

$$
\sum_{c=1}^{k} r_{c}=1 .
$$

Denote by $y_{j c}^{h}\left(O_{i}\right)$ - assessment $c$ - them expert $h$ - th indicator, belonging to $j$ - th characteristics of the object $O_{i}, i=\overline{1, l}, c=\overline{1, k}, h=\overline{1, m_{j}^{i}}, j=\overline{1, n_{i}}$. Generalized assessment $j$ - th object characteristics $O_{i}$ determined by the formula:

$$
\hat{y}_{j}\left(O_{i}\right)=\sum_{h=1}^{m_{j}^{i}} \sum_{c=1}^{k} \omega_{h} r_{c} y_{j c}^{h}\left(O_{i}\right),
$$

where $\hat{y}_{j}\left(O_{i}\right)$ - generalized assessment $j$-th object characteristics $O_{i}, j=\overline{1, n_{i}}, i=\overline{1, l}, \omega_{h}$ - weights of indicators, $h=1, m_{j}^{i}, r_{c}$ - coefficient of competence of experts, $c=1, k, y_{j c}^{h}\left(O_{i}\right)$ - rating $c$ - th expert $h$ - th indicator, belonging to $j$ - th characteristics $i$ - th object.

Once you have received a generalized evaluation of the characteristics based on the evaluation of their parameters, it is necessary to find the evaluation of the characteristics without taking into account their parameters. To do this, it is necessary to conduct another round of questionnaires, in which members of the expert group assess the characteristics that determine the quality of resource provision, implementation of management functions and performance of the construction company. [12]

If through $v_{j}$ denote the normalized weights of the characteristics in the overall assessment, $j=\overline{1, n}_{i}, i=\overline{1, l}$, for which it is performed

$$
\sum_{j=1}^{n_{i}} v_{j}=1, i=\overline{1, l}
$$

and through $x_{c}^{j}\left(O_{i}\right)$ - assessment $c$-th expert $j$-th object characteristics $O_{i}, i=\overline{1, l}, c=\overline{1, k}$, $j=\overline{1, n_{i}}$, then the overall score $i$-th object without prior evaluation of the parameters will be determined by the formula:

$$
\hat{x}\left(O_{i}\right)=\sum_{j=1}^{n_{i}} \sum_{c=1}^{k} v_{j} r_{c} x_{c}^{j}\left(O_{i}\right), i=\overline{1, l}
$$

where $r_{c}$ - coefficient of competence of experts, $\hat{x}\left(O_{i}\right)$ - generalized assessment $i$ - th object.

In order to take into account preliminary estimates of the parameters of the characteristics, in this formula it is necessary to make the calculated estimates $\hat{y}_{j}\left(O_{i}\right)$. This can be done by entering a numeric parameter $\alpha \in[0,1]$, which will determine which of the two evaluations of 
characteristics $x_{c}^{j}\left(O_{i}\right)$ або $\hat{y}_{j}\left(O_{i}\right)$ to prefer. If the value $\alpha$ closer to zero, the advantage in the generalized evaluation of the object will be estimated $\hat{y}_{j}\left(O_{i}\right)$. If the value $\alpha$ closer to one - it is estimated $x_{c}^{j}\left(O_{i}\right)$. The value of this parameter is determined by experts, but it can always be balanced by taking the value $\alpha=0.5$.

Therefore, the generalized expert assessment of the object taking into account the preliminary assessment of the parameters of the characteristics is determined by the formula:

$$
\hat{x}\left(O_{i}\right)=\sum_{j=1}^{n_{i}} v_{j}\left(\alpha \sum_{c=1}^{k} r_{c} x_{c}^{j}\left(O_{i}\right)+(1-\alpha) \hat{y}_{j}\left(O_{i}\right)\right), i=\overline{1, l},
$$

where $\hat{x}\left(O_{i}\right)$ - generalized expert assessment of the object taking into account the preliminary assessment of the parameters of the characteristics, $x_{c}^{j}\left(O_{i}\right)$ - assessment $c$ th експертом $j$ - th object characteristics $O_{i}, \hat{y}_{j}\left(O_{i}\right)$ - generalized assessment $j$ - th object characteristics $O_{i}$, which is determined on the basis of a preliminary expert evaluation of the parameters of the characteristics, $\alpha \in[0,1]$ - a parameter that determines the superiority of performance estimates, $v_{j}$ - normalized weights of characteristics, $\sum_{j=1}^{n_{i}} v_{j}=1, r_{c}$ - coefficients of competence of experts, $\sum_{c=1}^{k} r_{c}=1$.

If the coefficients of competence and advantages of assessments of characteristics and parameters are not calculated, it is proposed to choose the following values:

$$
r_{c}=\frac{1}{k}, c=\overline{1, k}
$$

where $k$ - number of experts,

$$
v_{j}=\frac{1}{n_{i}}, j=\overline{1, n_{i}}, i=\overline{1, l},
$$

where $n_{i}$ - the number of characteristics of the object $O_{i}, i=\overline{1, l}$,

$$
\omega_{h}=\frac{1}{m_{j}^{i}}, h=\overline{1, m_{j}^{i}}, j=\overline{1, n_{i}}, i=\overline{1, l},
$$

where $m_{j}^{i}$ - number of parameters $j$ - th object characteristics $O_{i}, i=\overline{1, l}$.

The described formulas for calculation of the generalized estimations of objects in the developed expert-analytical model of estimation of quality of management are used for objects. $\mathrm{O}_{1}$ and $\mathrm{O}_{2}$. Because the object $\mathrm{O}_{3}$ has characteristics without parameters, the evaluation will be carried out only at the level of characteristics. In this case, we will apply the formula 13 $[1,3-4,6-9]$.

\section{Conclusion}

The content and stages of the expert-analytical model of quality assessment of management of the studied enterprises should be directed towards the creation of a holistic technology that would combine qualimetric, diagnostic and prognostic properties and which would allow to identify priorities for construction enterprises. At the same time, the improved tools should be aimed at successfully solving a number of inverse problems - to prove to the customer (at the beginning of the preparatory phase of the investment cycle) of the construction project 
functional, technical, economic and organizational reliability of construction companies as a potential executor. Dynamic analysis of the integrated indicator of management quality allows the institutional level of contractors to rationally plan the activities of the construction company and adjust the work in those sectors (financial, production, resource, etc.) for which negative assessments were obtained based on the results of the examination.

\section{References}

1. Ryzhakova, G., Ryzhakov, D., Petrukha, S., Ishchenko, T., \& Honcharenko, T. (2019). The Innovative Technology for Modeling Management Business Process of the Enterprise. International Journal of Recent Technology and Engineering (IJRTE), 8 (4), 4024-4033.

2. Kulikov, P.M. (2019). Enterprise management: principles and individual functions in modern conditions. Monograph / [V. G. Fedorenko and others; for order. VG Fedorenko]; Europe. business assembly [etc.]. Kyiv: DKS Center, 386.

3. Chupryna, Yu.A. (2019). Methodology of integration of stakeholder potential into the construction cluster. Formation of market relations in Ukraine. Collection of scientific works, №1 (212) (KyivDNDIIME), 85-91.

4. Chupryna, Yu.A. (2019). Involvement of applied advantages of bim-technologies in the methodology and practice of forming the life cycle of projects as part of state target programs, which are embodied in the construction cluster. Economy and State, no. 3, 67-70.

5. Ivakhnenko, I.S. (2019). The role of stakeholders in ensuring the implementation of development in construction. Management of complex systems development. Kyiv, KNUBA, no. 39, 112-117.

6. Fedorenko, V.G. (2010). Improving the management of construction companies in Ukraine by implementing process management. Efektyvna ekonomika: elektronne naukove fakhove vydannia / Dnipropetrovsk State Agrarian University, no. 11 [Electronic resource]. - Access mode: http://www. economy.nayka.com.ua.

7. Pokolenko, V.O. (2017). Mathematical formalization of the model of implementation of the portfolio of investment construction projects and its adaptation to the needs of the investor // Collection of scientific works "Ways to increase the efficiency of construction in terms of market relations". Vip. 35. Economic. KNUBA, 80-90.

8. Leach, V. (2016). Market economy: theoretical foundations of genesis. Monograph. K: LLC «DKS Center», 316.

9. Stetsenko, S., Hryhorovskyi, P. Ye., Menejljuk, O. I., Khyzhniak, V. O., \& Ryzhakova, G. M. Multiple criteria models for proving investment and construction project efficiency. Organizational and technological model engineering in the construction industry: collective monograph - Lviv-Toruń Liha-Pres. SENSE.

10. Goiko, A.F. (2018). Theoretical and methodological principles of formation and implementation of strategies for investment development of the region [Text]. Ways to increase the efficiency of construction in the formation of market relations, no. 38, 3-13.

11. Belenkova, O.Yu., \& Shaotsin, G. (2016). System of management of efficiency of reconstruction of housing stock on the basis of economic development. Standardization of engineering construction. 1, 356-357.

12. Pys'mennyy, O.M., Fedorenka, V.H., \& Ryzhakova, G.M. (2015). Modern tools and software products for quality assessment of construction management companies [Text]. Investment and innovation development in the context of economic security of the enterprise: col. monograph / ed. K .: IPK DSZU, 229-268. 